DOI 10.12737/article_5afc00054a78a7.32896031

УДК 633.853.52(571.1)

НОВЫЙ СОРТ СОИ КРАСНООБСКАЯ В УСЛОВИЯХ СЕВЕРНОГО ЗАУРАЛЬЯ

Ренев Е.П., Вьюшина О.А.

Реферат. Представлены результаты полевых испытаний при возделывании сои сорта Краснообская, выведенного совместно учеными НИИСХ С3 - филиала ТюмНЦ СО РАН (Тюменская обл.) и СФНЦА РАН (Новосибирская обл.), путем индивидуального отбора сомаклональных линий из сорта сои СибНИИК 315. Проведена оценка хозяйственно-морфологических признаков нового сорта сои Краснообская при возделывании ее на темно-серых лесных почвах в северной лесостепи Северного Зауралья. Сорт - скороспелый, продолжительность вегетационного периода - 79-95 дней, предназначен для зернового использования. Урожайность за годы конкурсного сортоиспытания (СФНЦА РАН, Новосибирск) составила в среднем 2,07 т/га, на 0,31 т/га выше стандарта СибНИИК 315. Максимальная урожайность семян - 2,42 т/га. По результатам исследований в условиях северной лесостепи Тюменской области новый сорт сои Краснообская скороспелого типа созревания показал удовлетворительные результаты по морфологии развития растений, продуктивности и качеству семян. Морфологически прикрепление нижнего боба выше на 1,1 см, чем у сорта СибНИИК 315 , содержание белка в зерне сои Краснообская в среднем за 2 года составило $34,0 \%$, выше стандарта на 2,2\%, жира - 19,6\% - на уровне стандарта. Урожайность сорта за 2 года исследований превышала стандарт СибНИИК 315 в среднем на 0,08 т/га или на $10,6 \%$.

Ключевые слова: соя, сорт, фенология, структурный анализ, урожайность, качество зерна.

Введение. Соя (Glycine $\max$ L. (Merr.) важнейшая белково-масличная культура мирового значения. Ее семена содержат в среднем 37 - 42\% белка, 19 - 22\% масла и до $30 \%$ углеводов; вегетативная масса, убранная в фазу налива бобов, богата белками $(16-18 \%)$, углеводами и витаминами.

В последнее десятилетие сильно увеличилось производство сои в мировом земледелии. Соя среди всех зернобобовых культур особо отличается всеми питательными веществами, необходимыми для нормальной жизнедеятельности человека и животных, а потому в мировой практике ей придается первостепенное значение в решении белковой проблемы. Протеины сои по своему аминокислотному составу близки к протеинам мяса. Соевое масло (15 -26 \% от массы семян) используется в пищевой и кормовой промышленности [1- 4].

В Сибири посевы сои не велики из-за недостатка тепла и сортов, адаптированных к местным климатическим условиям. Первый сибирский сорт сои СибНИИК 315, созданный В.Е. Гориным с соавт., включен в Государственный реестр РФ с 1991 г. и допущен к использованию в пяти регионах России и Казахстане. В лесостепной зоне Западной Сибири он вызревает за 90-110 дней, дает до 3 т/га семян с содержанием белка 35-40\%, масла 17-20\% [5]. Сибирские сорта Омская 4, Алтом, СибНИИСХоз 6, Дина, Эльдорадо, Золотистая, Надежда, Сибирячка, допущенные к возделыванию в 1993-2013 гг. в Западной Сибири и в других регионах, достаточно засухоустойчивы, имеют урожайность 1,5-2,5 т/га [6, 7, 8].Однако потребность в новых сортах сибирского направления с повышенной продуктивностью и вы- соким прикреплением нижних бобов, попрежнему актуальна.

Цель исследований - оценить продуктивность нового сорта сои Краснообская при возделывании ее в условиях Северного Зауралья.

Условия, материалы и методы исследований. Сорт сои Краснообская - начало государственного испытания - 2016 г. За стандарт взят исходный сорт - СибНИИК 315.

Полевой питомник был заложен в 20152016 гг. на опытном поле НИИСХ Северного Зауралья (Тюменская обл.). Предшественник пар. Размещение делянок в опыте - системати-

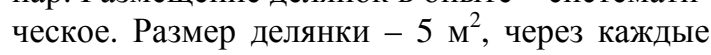
десять делянок высеян стандарт СибНИИК 315. Отбор растений для структурного анализа проводился в середине делянки по 10 растений в 4-х повторениях. Посев проводился вручную широкорядным способом во второй декаде мая, ширина междурядий - 45 см., по методике ВИР [9]. Химический состав и технологические качества зерна определяли в аналитической лаборатории НИИСХ Северного Зауралья. Математическая обработка данных проведена по Б.А. Доспехову [10]. Почва под опытом - темно-серая лесная тяжелосуглинистая. Глубина гумусного горизонта - 2527 см, содержание гумуса - 4,2-5,0\%, pH солевой вытяжки - 6,0-6,4. Весной общепринятая предпосевная обработка почвы.

Метеоусловия в годы исследований были различны по температурному режиму и выпадению осадков, в 2015 году обеспеченность осадками была хорошей. За период май-август выпало 281 мм, что составило $115 \%$ к среднемноголетней норме. В начальный период вегетации отмечалась засушливость 2-й и 3-й де- 
кад июня, ГТК=0,45 и 0,18 и 2-й декады июля, $\Gamma \mathrm{TK}=0,44$. Среднесуточная температура воздуха в эти месяцы составляла 126 и 125\% к среднемноголетнему показателю. В 3-й декаде июля и августа, наоборот, отмечался некоторый дефицит тепла. Среднесуточная температура в эти месяцы составляла $88 \%$ к среднемноголетнему показателю. Недостаток осадков наблюдался и в 2016 году (61\%) от нормы, c повышенной обеспеченностью теплом (131\%), с засушливостью большей части вегетационного периода - ГТК 0,10 - 0,54. Исключение составили 2-я декада июня и июля ГТК 1,66 и 3,42.

Анализ и обсуждение результатов исследований. Включенный в испытание сорт сои Краснообская выведен методами сомаклональной изменчивости и многократного индивидуального отбора.

Сорт относится к маньчжурскому подвиду, среднесеменной разновидности. Форма роста прямостоячая, тип развития - промежуточный, верхушка - прямая или завивающаяся, высота растения в зависимости от условий выращивания - 64-103 см, высота прикрепления нижнего боба - 11-20 см. Соцветие - пазушная кисть с 2-6 цветками, окраска венчика цветка - фиолетовая. Бобы длиной до 4 см, слабоизогнутые, число семян в бобе - 1-3. Количество бобов на растении - до 48, масса семян - до 15 г, масса 1000 - семян 127-173 г.

Сорт Краснообская отличается засухоустойчивостью: в 2012 г. в конкурсном сортоиспытании с ГТК 0,2 по семенной продуктивности на 29\% превзошёл стандарт СибНИИК 315. Практически не полегает, устойчив к растрескиванию бобов, более устойчив к бактериозу и фузариозу, чем стандарт СибНИИК 315 , отличается повышенным содержанием белка в семенах: от 39,0 до 41,9\% (в среднем на $1,6 \%$ выше, чем у стандарта СибНИИК315). Содержание жира в семенах - 17,5$18,9 \%$ (на уровне стандарта).

В государственном испытании 2016 г. вегетационный период сои сорта Краснообская составлял от 81 (Башкортостан, Дюртюлинский с/у) до 106 (Челябинская обл., Варненский $\mathrm{c} / \mathrm{y}$ ) суток. Наибольшая урожайность в 2016 г. получена на Горьковском с/y, Омской обл. - 2,2 т/га. В части регионов Российской
Федерации (Омская обл., Новосибирская обл., Алтайский край, Челябинская обл.) обеспечивал прибавку урожая (0,18-0,23 т/га). Предлагается к испытанию в Уральском и ЗападноСибирском регионах.

При возделывании нового сорта сои Краснообская в северной лесостепи Тюменской области на темно-серой лесной почве в условиях вегетационных периодов 2015-2016 гг. получены следующие результаты.

В 2015 г. период вегетации сои сорта Краснообская от посева до полного созревания составил 98 дней, в 2016 - 101 день, чуть раньше, чем у стандарта появились всходы, цветение наступило раньше - на 1-2 дня. В среднем за два года наблюдений вегетационный период у нового сорта составил 99 дней, что на 3 дня короче, чем у стандарта - 102 дня (табл. 1).

Очень важен такой метод оценки развития растений сои, как структура урожая, при котором мы можем проследить, как формируется будущий урожай в зависимости от погодных условий, влияния болезней, вредителей, сорной растительности и прочих факторов окружающей среды.

При проведении структурного анализа соя сорта Краснообская в 2015 г. сформировала растения высотой 95 см., высота прикрепления нижнего боба - 10,1 см., чуть выше стандарта на 0,3 см., масса 1000 семян - 173,7 г., что превышает стандарт СибНИИК 315 на 5,2 г, где соответственно - 168,5 г.

Дефицит влаги 2016 года (июль-август) негативно повлиял на формирование элементов урожая сои, семена были более мелкими и щуплыми, в сравнении с 2015 годом. Высота растений была не более 70 см., высота прикрепления нижнего боба - 9,6 см, масса 1000 семян - 143,7 г., выше стандарта на 3,2 г. В среднем за два года исследований высота растений Краснообской составила 78 см, на уровне стандарта, масса 1000 семян - 158,7, что выше СибНИИК 315 на 4,2 г., а по одному из основных показателей продуктивности сорта прикреплению нижнего боба превышала его на 1,1 см. (табл. 2).

В условия 2 лет исследований соя сорта Краснообская по урожайности достоверно превышал стандарт в 2015 году на 0,13 т/га, и

Таблица 1 - Фенологические наблюдения в период вегетации

\begin{tabular}{|c|c|c|c|c|c|c|c|}
\hline Сорт & Дата посева & Всходы & Цветение & Налив бобов & Полный налив & Вегетационный период \\
\hline & \multicolumn{7}{|c|}{2015 г. } \\
\hline СибНИИК 315 (St) & 23.05 & 1.06 & 15.07 & 14.08 & 08.09 & 100 \\
\hline Краснообская & 23.05 & 30.05 & 14.07 & 13.08 & 05.09 & 98 \\
\hline & \multicolumn{7}{|c|}{2016 г. } \\
\hline СибНИИК 315 (St) & 23.05 & 1.06 & 23.07 & 15.08 & 12.09 & 104 \\
\hline Краснообская & 23.05 & 1.06 & 20.07 & 14.08 & 09.09 & 101 \\
\hline
\end{tabular}


С Е Л СКОХО З ЯЙСТВЕННЫЕ НА УКИ

Таблица 2 - Результаты структурного анализа растений сои

\begin{tabular}{|c|c|c|c|c|c|c|c|}
\hline \multirow{2}{*}{ Сорт } & Год & $\begin{array}{c}\text { Высота раст., } \\
\text { см }\end{array}$ & $\begin{array}{c}\text { Высота прикрепления } \\
\text { нижнего боба, см. }\end{array}$ & $\begin{array}{c}\text { Кол-во бобов } \\
\text { с раст., шт. }\end{array}$ & $\begin{array}{c}\text { Кол-во зерен } \\
\text { с раст., шт. }\end{array}$ & $\begin{array}{c}\text { ВВес зерна } \\
\text { с раст., г }\end{array}$ & $\begin{array}{c}\text { Масса 1000 } \\
\text { зерен, г }\end{array}$ \\
\hline \multirow{2}{*}{$\begin{array}{c}\text { СибНИИК } \\
315(\mathrm{St})\end{array}$} & 2015 & 95,5 & 9,8 & 24,1 & 52,2 & 7,0 & 168,5 \\
\cline { 2 - 8 } & 2016 & 61 & 8,7 & 53 & 98,3 & 1,4 & 140,5 \\
\cline { 2 - 8 } & среднее & 78,3 & 9,2 & 38,5 & 75,2 & 9,2 & 154,5 \\
\hline \multirow{3}{*}{ Красно-обская } & 2015 & 95 & 11,1 & 27,0 & 54,2 & 8,2 & 173,7 \\
\cline { 2 - 8 } & 2016 & 60,8 & 9,6 & 55,5 & 103,3 & 12,2 & 143,7 \\
\cline { 2 - 8 } & среднее & 78,0 & 10,3 & 41,3 & 78,7 & 10,2 & 158,7 \\
\hline
\end{tabular}

Таблица 3 - Урожайность и качество семян сои, (2015-2016 гг.)

\begin{tabular}{|c|c|c|c|c|}
\hline \multirow{2}{*}{ Сорт } & Год & Урожайность, т/га & Белок, \% & Жир, \% \\
\hline \multirow{3}{*}{ СибНИик 315 (St) } & 2015 & 1,15 & 33,1 & 18,4 \\
\cline { 2 - 5 } & 2016 & 1,29 & 31,3 & 21,0 \\
\hline \multirow{3}{*}{ Краснообская } & среднее & 1,22 & 32,2 & 19,7 \\
\cline { 2 - 5 } & 2015 & 1,28 & 36,4 & 18,3 \\
\cline { 2 - 5 } & 2016 & 1,32 & 31,4 & 21,1 \\
\hline НСР $_{05}$ & среднее & 1,30 & 34,0 & 19,6 \\
\hline
\end{tabular}

в 2016 году был на уровне стандарта при $\mathrm{HCP}_{05}=0,1$, а в среднем за два года незначительно превышал стандарт СибНИИК 315 - на 0,08 т/га или на 10,6\%.

Содержание белка в зерне сои Краснообская в среднем за 2 года составило $34,0 \%$, выше стандарта на 2,2\%, жира - 19,6\% - на уровне стандарта (табл. 3).

Выводы. По результатам исследований в условиях северной лесостепи Тюменской области новый сорт сои Краснообская скороспе- лого типа созревания показал удовлетворительные результаты по морфологии развития растений, продуктивности и качеству семян. Морфологически прикрепление нижнего боба выше на 1,1 см, чем у сорта СибНИИК 315 , содержание белка в зерне сои Краснообская в среднем за 2 года составило 34,0\%, выше стандарта на 2,2\%, жира - 19,6\% - на уровне стандарта. Урожайность сорта за 2 года исследований превышала стандарт СибНИИК 315 в среднем на 0,08 т/га или на 10,6\%.

Литература

1. Федотов В.А. Соя в России: (монография) / В.А. Федотов, С.В. Гончаров, О.В. Столяров и др.; под ред. профессоров В.А. Федотова и С.В. Гончарова. - Москва: Агролига России, 2013. - 432 с.

2. Закиева А.А. Сравнительное экологическое изучение ультроскороспелых сортов и селекционных номеров сои в условиях Костонайской и Алматинской областях / А.А. Закиева, А.Р. Искаков, И.В. Сидорик, С.В. Дидоренко // Казахский национальный аграрный университет. - Алматы, 2015. - №1 (обращение в интерн. 10.12.2016 г).

3. Каманина Л.А. Формирование качества семян сои сорта Лазурная в зависимости от условий выращивания // Земледелие. - 2016. - № 5. - С. 43-45.

4. Кшникаткина А.Н. Агроэкологическое изучение сортов сои и совершенствование технологии их возделывания / А.Н. Кшникаткина // Нивы Поволжья. - 2015. - № 1 (34). - С. 14-19

5. Рожанская О.А., Полюдина Р.И. Особенности селекции сои с использованием методов сомаклональной и мутагенеза в условиях Западной Сибири / О.А. Рожанская, Р.И. Полюдина // Сиб. вестн. с.-х. науки. 2012. - №4. - C. 69-76.

6. Рожанская О.А. Новые сомаклональные линии сои для селекции в Сибири / О.А. Рожанская, Т.Г. Ломова, Т.В. Шилова, Е.М. Горшкова // Сиб. вест. с.-х. науки. - 2016. - №2 - - С. 35-42.

7. Мерзляков А.И. Результаты выращивания сои в Тюменской области / А.И. Мерзляков, А.Д. Вольнюк // Сельскохозяйственные науки и агропромышленный комплекс на рубеже веков. - 2015. - № 5. - С. 111-114.

8. Иваненко А.С. Соя в Тюменской области в 2014 году / А.С. Иваненко, Л.И. Мерзляков // Селекция и семеноводство сельскохозяйственных культур. - 2014. - № 3.- С. 3-7. 39.

9. Методические указания по изучению коллекции зерновых бобовых культур. - Л.: ВИР, 1975. - С. 3 -

10. Доспехов Б.А. Методика полевого опыта / Б.А. Доспехов. - М.: Колос, 1979. - 415с.

Сведения об авторах:

Ренев Евгений Петрович - кандидат, сельскохозяйственных наук, e-mail: vyushina63@mail.ru Вьюшина Ольга Анатольевна - научный сотрудник, e-mail: vyushina63@mail.ru

Научно-исследовательский институт сельского хозяйства Северного Зауралья - филиал ТюмНЦ СО РАН , Тюменская область, Тюменский район, пос. Московский, Росия. 


\section{KRASNOOBSKAYA - NEW VARIETY OF SOYBEAN IN THE CONDITIONS OF NORTH URALS}

\section{Renev E.P., Vyushina O.A.}

Abstract. The article presents field trials results of Krasnoobskaya variety soybean cultivation, developed jointly by the scientists of Scientific Research Institute of Agriculture of North Urals - branch of Tyumen Scientific Center of the Siberian branch of Russian Academy of Sciences, (Tyumen region) and Siberian Federal Scientific Center of Agrobiotechnologies of Russian Academy of Sciences (Novosibirsk Region) are presented by individual selection of somaclonal lines from Siberian Research Institute of Feedstuff 315 type of soybean. An economic morphological signs of a new Krasnoobskaya variety of soybean was conducted when growing it on dark gray forest soils in the northern forest-steppe of the Northern Urals. The variety is early maturing, the duration of the growing season is 79-95 days, it is intended for grain use. The productivity for the years of competitive testing (Siberian Federal Scientific Center of Agrobiotechnologies of Russian Academy of Sciences, Novosibirsk) averaged 2.07 tons per hectare, 0.31 tons per hectare higher than Siberian Research Institute of Feedstuff 315 type. The maximum yield of seeds is 2.42 tons per hectare. According to the results of research in the conditions of the northern forest-steppe of Tyumen region, Krasnoobskaya - a new variety of soybean of early maturation type showed satisfactory results in the morphology of plant development, productivity and seed quality. Morphologically, the attachment of the lower bean is $1.1 \mathrm{~cm}$ higher than that of Siberian Research Institute of Feedstuff 315 type, the average protein content in the Krasnobobskaya soybean was $34.0 \%$ on average over 2 years, $2.2 \%$ higher than the standard, and $19.6 \%$ higher in fat standard level. The productivity of the variety for 2 years of research exceeded the standard of Siberian Research Institute of Feedstuff 315 type by an average of 0.08 tons per hectare or $10.6 \%$.

Key words: soybean, variety, phenology, structural analysis, productivity, grain quality.

\section{References}

1. Fedotov V.A. Soya v Rossii: (monografiya). [Soy in Russia: (monograph)]. / V.A. Fedotov, S.V. Goncharov, O.V. Stolyarov and others; edited by professors V.A. Fedotov and S.V. Goncharov. - Moskva: Agroliga Rossii, 2013. - P 432.

2. Zakieva A.A. Sravnitelnoe ekologicheskoe izuchenie ultroskorospelykh sortov i selektsionnykh nomerov soi $v$ usloviyakh Kostonayskoy $i$ Almatinskoy oblastyakh. [Comparative ecological study of ultra-fast-ripening varieties and soybean breeding numbers in the conditions of Kostonai and Almaty regions]. / A.A. Zakieva, A.R. Iskakov, I.V. Sidorik, S.V. Didorenko // Kazakhskiy natsionalnyy agrarnyy universitet (ISSLEDOVANIYa, REZULTATY). Almaty, 2015. - №1 (obraschenie v intern. 10.12.2016g).

3. Kamanina L.A. Formation of quality of soybean seeds of Lazurnaya variety depending on growing conditions. [Formirovanie kachestva semyan soi sorta Lazurnaya v zavisimosti ot usloviy vyraschivaniya]. // Zemledeliye. - Agriculture. - 2016. - № 5. - P. 43-45.

4. Kshnikatkina A.N. Agroecological study of soybean varieties and improvement of its cultivation technology. [Agroekologicheskoe izuchenie sortov soi i sovershenstvovanie tekhnologii ikh vozdelyvaniya]. / A.N. Kshnikatkina // Niva Povolzhya. - Niva Volga. - 2015. - № 1 (34). - P. 14-19

5. Rozhanskaya O.A., Polyudina R.I. Peculiarities of soybean selection with the use of somaclonal and mutagenesis methods in Western Siberia. [Osobennosti selektsii soi s ispolzovaniem metodov somaklonalnoy i mutageneza v usloviyakh Zapadnoy Sibiri]. / O.A. Rozhanskaya, R.I. Polyudina // Sib. vestn. s.-kh. nauki. - Siberian Herald of Agriulture. 2012. - №4. - P. 69-76.

6. Rozhanskaya O.A. New somaclonal soybean lines for breeding in Siberia. [Novye somaklonalnye linii soi dlya selektsii v Sibiri]. / O.A. Rozhanskaya, T.G. Lomova, T.V. Shilova, E.M. Gorshkova // Sib. vestn. s. kh. nauki. - Siberian Herald of Agriulture. - 2016. - №2. - P. 35-42.

7. Merzlyakov A.I. Results of soybean cultivation in Tyumen region. [Rezultaty vyraschivaniya soi v Tyumenskoy oblasti]. / A.I. Merzlyakov, A.D. Volnyuk // Selskokhozyaystvennye nauki i agropromyshlennyy kompleks na rubezhe vekov. - Agricultural sciences and agro-industrial complex at the turn of the century. - 2015. - №5. - P. 111-114.

8. Ivanenko A.S. Soybean in Tyumen region in 2014. [Soya v Tyumenskoy oblasti v 2014 godu]. / A.S. Ivanenko, L.I. Merzlyakov // Selektsiya i semenovodstvo selskokhozyaystvennykh kultur. - Selection and seed-growing of agricultural crops. - 2014. - №3. - P. 3-7.

9. Metodicheskie ukazaniya po izucheniyu kollektsii zernovykh bobovykh kultur. [Methodological guidelines for studying the grain legumes collection]. - L.: VIR, 1975. - P. 3-39.

10. Dospekhov B.A. Metodika polevogo opyta. [Methodology of field experience]. / B.A. Dospekhov. - M.: Kolos, 1979. - P. 415

Authors:

Renev Evgeniy Petrovich - Ph.D. of Agricultural Sciences, acting Director, Tyumen, Russia

Vyushina Olga Anatolevna* - scientific researcher, Tyumen, Russia

Research Institute of Agriculture of North Urals - Siberian Branch of Tyumen Scientific Center of Russian Academy of Sciences. Burlaki Street, 2, township Moskovskiy, Tyumen district, Tyumen region, 625501, Russian Federation, e-mail: vyushina63@mail.ru 